\title{
Dramatically improved RNA in situ hybridization signals using LNA-modified probes
}

\author{
RUNE THOMSEN, ${ }^{1}$ PETER STEIN NIELSEN, ${ }^{2}$ and TORBEN HEICK JENSEN ${ }^{1}$ \\ ${ }^{1}$ Centre for mRNP Biogenesis and Metabolism, Department of Molecular Biology, Aarhus University, DK-8000 Aarhus C, Denmark \\ ${ }^{2}$ Department of Functional Genomics, Exiqon, DK-2950 Vedbaek, Denmark
}

\begin{abstract}
In situ detection of RNA by hybridization with complementary probes is a powerful technique. Probe design is a critical parameter in successful target detection. We have evaluated the efficiency of fluorescent DNA oligonucleotides modified to contain locked nucleic acid (LNA) residues. This increases the thermal stability of hybrids formed with RNA. The LNA-based probes detect specific RNAs in fixed yeast cells with an efficiency far better than conventional DNA oligonucleotide probes of the same sequence. Using this probe design, we were also able to detect $\operatorname{poly}(\mathrm{A})^{+} \mathrm{RNA}$ accumulation within the nucleus/ nucleolus of wild-type cells. LNA-based probes should be readily applicable to a diverse array of cells and tissue samples.
\end{abstract}

Keywords: RNA-FISH; LNA; nuclear foci; $\operatorname{poly}(\mathrm{A})^{+}$RNA

In situ hybridization (ISH) offers the advantage of studying the expression level and localization of RNA within single cells. The technique is applicable to virtually all types of eukaryotic cells ranging from yeast to human origin, and is also successfully used for probing of tissue sections or whole-mount preparations. With the rapid development of microscopes and software for image acquisition, the usage of fluorescence is nowadays the preferred method of detection. DNA oligonucleotides have become popular probes for RNA fluorescent ISH (RNA-FISH) analysis, as these can be synthesized chemically, allowing for incorporation of aminomodified nucleotides, which can subsequently be directly coupled to a fluorophore of interest (Chartrand et al. 2000). On top of this facile and reproducible probe preparation method, oligonucleotides often produce high signal-to-noise ratios because of their relatively low sequence complexity. However, this is clearly counterproductive in terms of binding affinity when compared to longer probes.

The usage of locked nucleic acid (LNA)-modified oligonucleotide probes has been shown to significantly improve the sensitivity and specificity of microRNA detection (Valoczi et al. 2004; Wienholds et al. 2005). LNA oligonu-

Reprint requests to: Torben Heick Jensen, Centre for mRNP Biogenesis and Metabolism, Department of Molecular Biology, Aarhus University, C.F. Møllers Alle, Bldg. 130, DK-8000 Aarhus C, Denmark; e-mail: thj@mb.au.dk; fax: 4586196500.

Article published online ahead of print. Article and publication date are at http://www.rnajournal.org/cgi/doi/10.1261/rna.2139705. cleotides are a new class of bicyclic RNA analogs that exercise an unprecedented high affinity for their complementary DNA or RNA targets (Koshkin et al. 1998). By using a design in which several positions in a conventional DNA oligonucleotide were substituted by LNAs, the sensitivity in detecting mature miRNAs by Northern blotting was increased by at least one order of magnitude (Valoczi et al. 2004). More recently, LNA-modified DNA-oligonucleotides were also used as FISH-probes on whole-mount zebrafish embryos to detect the temporal and spatial expression pattern of 115 conserved vertebrate miRNAs (Wienholds et al. 2005).

To evaluate the feasibility of LNA-modified probes for mRNA-FISH on fixed yeast cells, we compared the intensity of heat-shock SSA4 RNA staining using progressively shorter LNA-modified or DNA probes containing a single fluorescent $\mathrm{Cy} 3$ label at their $5^{\prime}$-ends (Fig. 1A; Table 1). To be able to also examine signal specificity, the $\Delta$ ripl mRNA export mutant strain was used. At permissive growth conditions of $25^{\circ} \mathrm{C}, S S A 4$ transcripts are undetectable, whereas at nonpermissive conditions of $42^{\circ} \mathrm{C}, S S A 4$ transcription is induced and the strain accumulates SSA4 RNA in a single nuclear dot at or near its site of transcription. This accumulation has previously been detected by a combination of a 51-mer (KD199) and a 54-mer (KD200) DNA oligonucleotide probe, each harboring five amino-modified thymidine residues for attachment of Cy3 fluorophores (Jensen et al. 2001; Thomsen et al. 2003).

Both singly labeled 54-mer DNA-KD200 and LNA-KD200 probes reliably detected the SSA4 RNA signal in $\Delta$ ripl cells 
$\mathbf{A}$

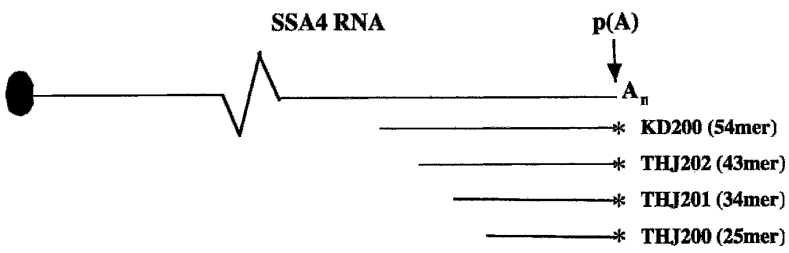

B

$\Delta$ rip $42^{\circ} \mathrm{C} 20^{\prime}$
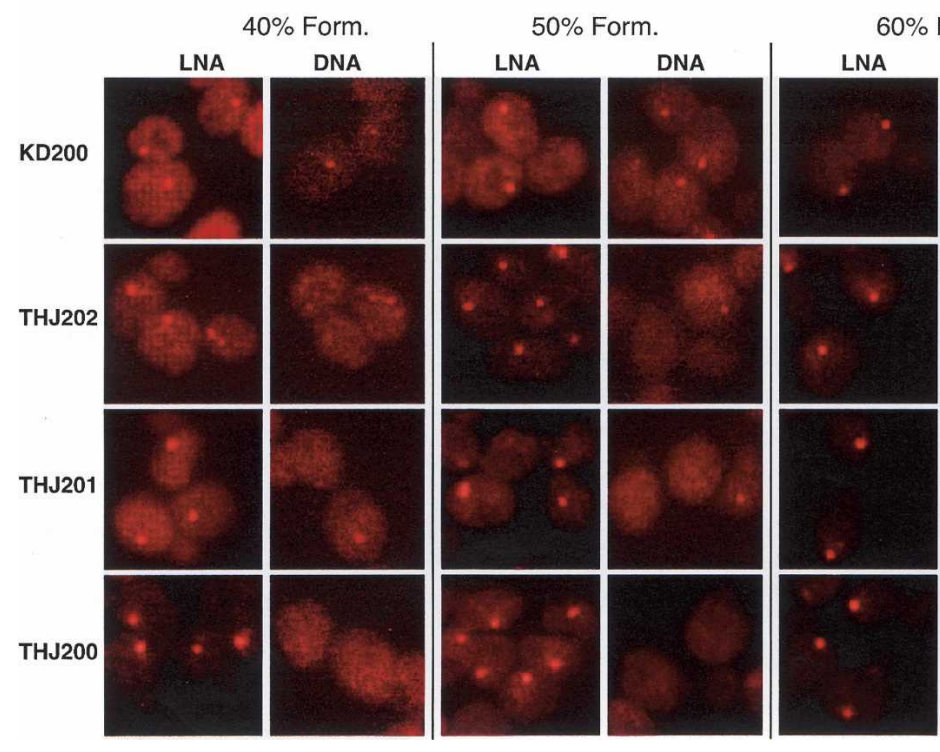

$0 \%$ Form.
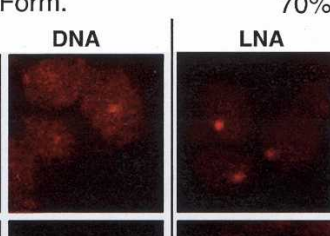

$70 \%$ Form.
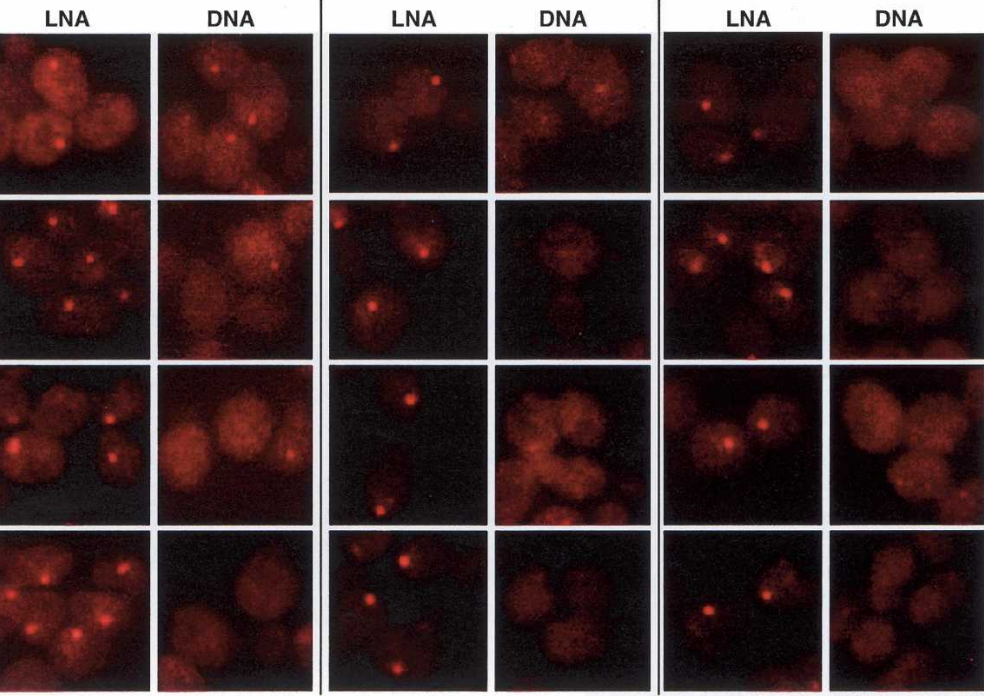

FIGURE 1. Short LNA-modified SSA4 RNA-FISH probes yield robust signals. (A) Schematic representation of the LNA/DNA probe design. The first, and fluorescently labeled, nucleotide of the probes is in all cases positioned at the SSA4 nucleotide immediately prior to the major poly(A)tail addition-site [denoted $\mathrm{p}(\mathrm{A})$ ]. $\mathrm{A}_{n}$ indicates the SSA4 RNA poly(A) tail. (B) SSA4 RNA-FISH analysis in the $\Delta$ rip1 mutant. Cells were grown at $25^{\circ} \mathrm{C}$ and fixed after a 20 -min temperature shift to $42^{\circ} \mathrm{C}$. This shift concomitantly induces SSA4 transcription and the $\Delta$ ripl-induced mRNA export phenotype. Fixed cells were analyzed by RNA-FISH using Cy3 $5^{\prime}$-end-labeled LNA-modified or DNA probes (Fig. 1A; Table 1) and progressively more stringent hybridization conditions as indicated.

subjected to a 20 -min heat pulse at $42^{\circ} \mathrm{C}$ (Fig. 1B, upper row, two first columns). However, with increasing hybridization stringencies, the DNA-KD200 signal was lost (Fig. 1B, upper row). In contrast, the LNA-KD200 probe still produced a robust signal even after hybridization in $70 \%$ formamide, reflecting the superior thermal stability of the LNA-RNA hybrid compared to the DNA-RNA hybrid. This relationship was underscored when analyzing progressively shorter LNA-modified probes. Remarkably, the short 25-mer LNATHJ200 probe still produced an excellent SSA4-FISH signal even when subjected to the most stringent hybridization conditions of $70 \%$ formamide (Fig. 1B, lower row, two last columns). In fact, under these conditions, much less background stain was detectable "outside the dot domain," indicating that the majority of SSA4 RNA in $\Delta$ rip1 after a 20-min heat pulse at $42^{\circ} \mathrm{C}$ is localized to this nuclear focus. Importantly, all utilized probes detected SSA4 RNA specifically, as FISH signals under inducing conditions $\left(42^{\circ} \mathrm{C}, 20 \mathrm{~min}\right)$ always overlapped the DAPI-stained DNA signal as expected and under noninducing conditions $\left(25^{\circ} \mathrm{C}\right)$ were absent from cells (data not shown).

TABLE 1. Oligonucleotide probes used in this study

\begin{tabular}{llccc}
\hline $\begin{array}{l}\text { Probe } \\
\text { name }\end{array}$ & Probe sequence $\left(5^{\prime}-3^{\prime}\right)$ & $T_{\mathrm{m}}{ }^{\mathrm{a}}\left({ }^{\circ} \mathrm{C}\right)$ & $\% \mathrm{LNA}$ & $T_{\mathrm{m}}{ }^{\mathrm{b}}\left({ }^{\circ} \mathrm{C}\right)$ \\
\hline KD200 & gagaacgtacaaatagtagtcatttgctaattactgattgtgtatcttatatat & 67 & 33.3 & 77 \\
THJ202 & gagaacgtacaaatagtagtcatttgctaattactgattgtgt & 68 & 32.6 & 79 \\
THJ201 & gagaacgtacaaatagtagtcatttgctaattac & 64 & 32.4 & 75 \\
THJ200 & gagaacgtacaaatagtagtcattt & 59 & 32.0 & 71 \\
THJ790 & tttttttttttttttt & 40 & 35.0 & 61 \\
\hline
\end{tabular}

The melting temperature $\left(T_{\mathrm{m}}\right)$ of individual probes (except for THJ790) was estimated using the $T_{\mathrm{m}}$ prediction tool accessible at http://www.exiqon.com. $T_{\mathrm{m}}{ }^{\mathrm{a}}$ represents the $T_{\mathrm{m}}$ for DNA probes, whereas $T_{\mathrm{m}}{ }^{\mathrm{b}}$ represents $T_{\mathrm{m}}$ for LNA-modified probes. Note that $T_{\mathrm{m}}$ predictions are based on hybridization to perfect-match DNA nucleotides. $T_{\mathrm{m}}$ for probe THJ790 is based on actual measurements against a ribo- $\mathrm{A}_{20}$ complement (Jacobsen et al. 2004). The degree of LNA modification is given in percentage of probe length. 


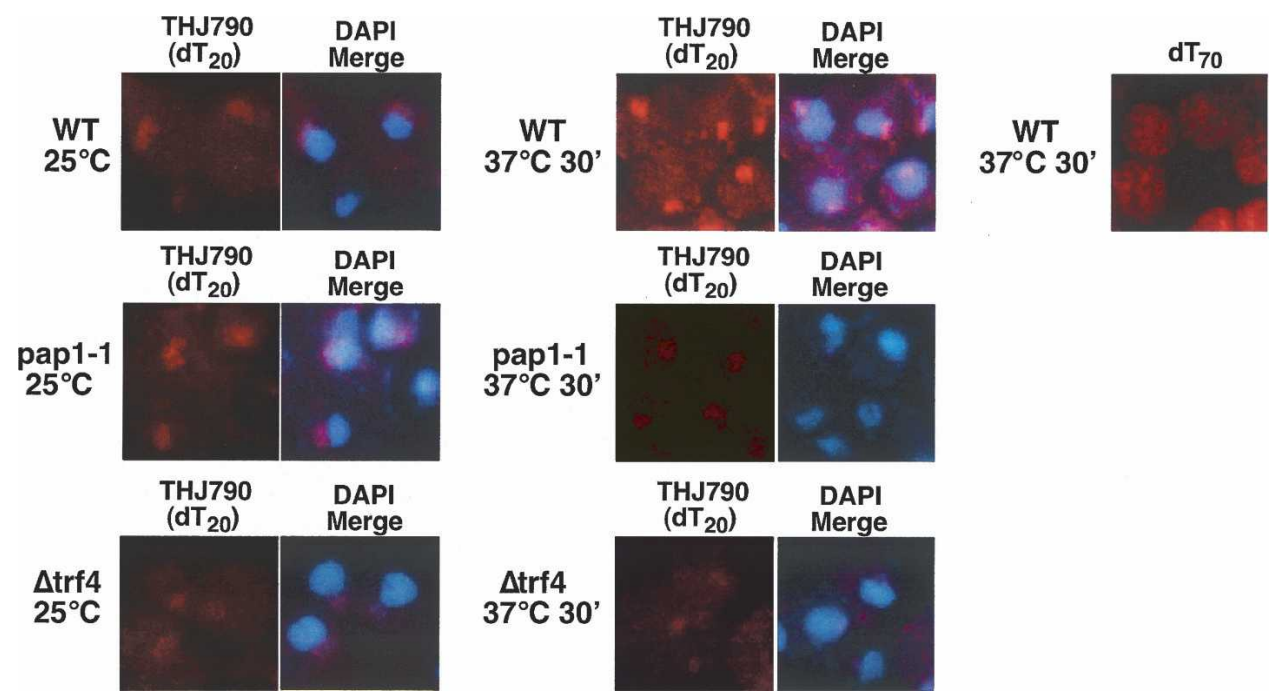

FIGURE 2. Poly(A) ${ }^{+}$RNA-FISH analysis of the wild-type (WT), pap1-1 and $\Delta$ trf4 strains. Cells grown at $25^{\circ} \mathrm{C}$ or temperature-shifted for 30 min to $37^{\circ} \mathrm{C}$ were fixed and analyzed by RNA-FISH using a Cy3 $5^{\prime}$-end-labeled LNA-modified $\mathrm{dT}_{20}$ probe (THJ790). For comparison, wild-type cells fixed after a temperature shift to $37^{\circ} \mathrm{C}$ for 30 min were also subjected to RNA-FISH using a $\mathrm{dT}_{70}$ DNA-oligonucleotide probe containing seven amino-modified thymidine residues for attachment of Cy3 fluorophores. To evaluate subnuclear localization, signals obtained using the THJ790 probe were overlaid with DAPI.

We also wished to evaluate the utility of an LNA-modified probe to detect poly $(\mathrm{A})^{+}$RNA. For this purpose, a $\mathrm{dT}_{20}$ probe (THJ790), harboring a single Cy3 label, was synthesized (Table 1). In pilot experiments using the $\Delta$ rip1 strain, this probe yielded overwhelmingly brighter nuclear signals than our conventionally used DNA-based $\mathrm{dT}_{70}$ probe harboring seven Cy3-labeling sites (data not shown). We therefore decided to also test the effect of THJ790 staining of wild-type cells. Without precedent, a nuclear signal, which could not be detected when using the $\mathrm{dT}_{70}$ probe, was detectable from fixed cells (Fig. 2, upper row). Interestingly, THJ790 signal intensity increased when these cells were temperature-shifted to $37^{\circ} \mathrm{C}$ for $30 \mathrm{~min}$ as compared to growth at $25^{\circ} \mathrm{C}$. Consistent with this observation, DNA microarray experiments show that the fraction of polyadenylated RNAs in a wild-type yeast cell increases at elevated temperatures (K. Abruzzi and M. Rosbash, pers. comm.). In addition, a substantial fraction of the THJ790 signal is positioned next to the DAPI stain, suggesting a nucleolar localization (Fig. 2, upper row). Which species of polyadenylated RNA(s) is detected by the THJ790 probe is not clear. Passage of polyadenylated mRNA through the nucleolus has previously been suggested (Schneiter et al. 1995). Consistently, introduction of the temperature-sensitive pap1-1 mutation of the conventional yeast mRNA poly(A) polymerase considerably decreases the THJ790 signal at the nonpermissive temperature (Fig. 2, middle row). However, a fraction of the nuclear pool of stable RNAs (snRNAs, snoRNAs, rRNAs, and tRNAs) has recently been shown to be turned over by the so-called TRAMP complex in a polyadenylation-dependent process requiring one of two newly identified poly(A)-polymerases, $\operatorname{Trf} 4 \mathrm{p}$ or Trf5p (Kadaba et al. 2004; LaCava et al. 2005; Vanacova et al. 2005; Wyers et al. 2005). Deletion of the TRF4 gene also lowers the $37^{\circ} \mathrm{C}$ THJ790 signal (Fig. 2, lower row). Future studies will aim to clarify exactly which polyadenylated RNAs contribute to the THJ790-derived signal.

In this paper, we have shown that LNA-modified FISH probes readily outperform conventional DNA probes in the detection of RNA in fixed yeast cells. In addition to their superior thermal properties in RNA binding, the increased efficiency of LNA-based FISH probes is supposedly due to their short sizes, resulting in better cell permeability and target accessibility. The latter might provide a clear advantage when targets are short; for example, oligo(A)-tails produced by TRAMP. As already shown for zebrafish embryos, this methodology should be readily adoptable to other cells and tissues.

\section{MATERIALS AND METHODS}

\section{Yeast strains}

The yeast strains used in this study are derived from W303 and have all been previously described: wild type (WT) and $\Delta$ rip1 (Stutz et al. 1997), $\Delta$ trf4 (Wyers et al. 2005), and pap1-1 (Dower et al. 2004).

\section{Preparation of yeast cells for RNA-FISH}

Growth, fixation, and preparation of cells as well as processing of these for FISH analysis were done as previously described 
(Jensen et al. 2001). Briefly, $10 \mathrm{~mL}$ cell cultures were grown at $25^{\circ} \mathrm{C}$ to an $\mathrm{OD}_{600}$ of $0.1-0.3$ and subjected to an instantaneous temperature shift by addition of pre-heated media. After incubation at the desired temperature, cells were fixed in $4 \%$ formaldehyde for $15 \mathrm{~min}$ at the experimental temperature followed by $30 \mathrm{~min}$ at $20^{\circ} \mathrm{C}$. Fixed cells were pelletted by centrifugation and washed three times in $1 \mathrm{~mL}$, and subsequently resuspended in 200-500 $\mu \mathrm{L}$, of wash buffer $\left(1.2 \mathrm{M}\right.$ sorbitol, $0.1 \mathrm{M} \mathrm{KH}_{2} \mathrm{PO}_{4} /$ $\mathrm{K}_{2} \mathrm{HPO}_{4}$ at $\mathrm{pH}$ 6.5). Then $10 \mu \mathrm{L}$ of the individual cell suspensions were plated on 14 -well, $0.1 \%$ poly-L-lysine coated glass slides (Immuno-Cell Int.) and washed in wash buffer containing $1 \% \beta$-mercaptoethanol before spheroplasting for $10-15 \mathrm{~min}$ at $30^{\circ} \mathrm{C}$ in $10 \mu \mathrm{L}$ of oxalyticase solution $(20 \mathrm{mM}$ vanadyl-ribonucleoside, $0.2 \% \beta$-mercaptoethanol, $0.1 \mathrm{U} / \mu \mathrm{L}$ RNasin, $1.2 \mathrm{M}$ sorbitol, $0.1 \mathrm{M} \mathrm{KH}_{2} \mathrm{PO}_{4} / \mathrm{K}_{2} \mathrm{HPO}_{4}$ at $\mathrm{pH} 6.5,0.1 \mathrm{mg} / \mathrm{mL}$ oxalyticase [Enzogenetics]). Subsequently, cells were washed for $5 \mathrm{~min}$ at $20^{\circ} \mathrm{C}$; twice in wash buffer, once in $0.1 \mathrm{M} \mathrm{KH}_{2} \mathrm{PO}_{4} / \mathrm{K}_{2} \mathrm{HPO}_{4}$ ( $\mathrm{pH} 6.5), 0.1 \% \mathrm{NP}-40$ and once in $0.1 \mathrm{M} \mathrm{KH}_{2} \mathrm{PO}_{4} / \mathrm{K}_{2} \mathrm{HPO}_{4}(\mathrm{pH}$ 6.5), and finally incubated with cold $70 \%$ ethanol for $15-30 \mathrm{~min}$ at $-20^{\circ} \mathrm{C}$.

\section{Probe preparation and RNA-FISH}

Probe preparation was done by direct labeling of 10-20 $\mu \mathrm{g}$ of oligonucleotide with $300 \mu \mathrm{g}$ of Cy3 (Amersham Pharmacia) in $0.1 \mathrm{M} \mathrm{NaHCO}_{3} / \mathrm{Na}_{2} \mathrm{CO}_{3}\left(\mathrm{pH} 9.0\right.$ ) overnight at $25^{\circ} \mathrm{C}$ in the dark followed by G-50 spin column purification. For each well, $100 \mathrm{ng}$ of probe was mixed with $10 \mu \mathrm{g}$ of salmon sperm DNA and $10 \mu \mathrm{g}$ of yeast tRNA, lyophilized and resuspended in $5 \mu \mathrm{L}$ of solution

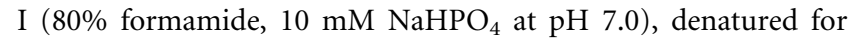
$5 \mathrm{~min}$ at $95^{\circ} \mathrm{C}$, and finally mixed with $5 \mu \mathrm{L}$ of solution II $(4 \times$ SSC, $20 \mathrm{mM}$ Vanadyl-ribonucleoside, $4 \mu \mathrm{g} / \mu \mathrm{L}$ BSA, $0.1 \mathrm{U} / \mu \mathrm{L}$ RNasin).

Prior to probe addition, cells were drained for ethanol and washed at $20^{\circ} \mathrm{C}$ twice for $5 \mathrm{~min}$ in $2 \times$ SSC and once for $10 \mathrm{~min}$ in $40 \%$ formamide $/ 2 \times$ SSC, $0.1 \%$ Triton X-100, before overnight incubation at $37^{\circ} \mathrm{C}$ with $10 \mu \mathrm{L}$ of probe mix. Probe removal was followed by washing steps: (1) twice in $40 \%$ formamide/ $2 \times$ SSC for $10 \mathrm{~min}$ at $37^{\circ} \mathrm{C}$; (2) once in $2 \times \mathrm{SSC} / 0.1 \%$ Triton $\mathrm{X}-100$ for $10 \mathrm{~min}$ at $20^{\circ} \mathrm{C}$; (3) twice in $1 \times$ SSC for $10 \mathrm{~min}$ at $20^{\circ} \mathrm{C}$; and (4) twice in $1 \times$ PBS for $5 \mathrm{~min}$ at $20^{\circ} \mathrm{C}$. Finally, $2.5 \mu \mathrm{L}$ of mounting solution $(1 \times \mathrm{PBS}$ at $\mathrm{pH}$ 8.0, $80 \%$ glycerol, $0.1 \mu \mathrm{g} / \mathrm{mL}$ DAPI) was applied to air-dried wells, which were subsequently covered with a coverslip and ready for analysis by fluorescent microscopy.

Increased hybridization stringencies were achieved by increasing the formamide concentration (normally 40\%) in hybridization and all appropriate wash buffers to $50 \%, 60 \%$, and $70 \%$, respectively. The probes used are listed in Table 1 . The LNA-modified probes are available from Exiqon (http://www.exiqon.com).

\section{Imaging}

Images were acquired on an Olympus BX51 microscope equipped with a cooled Olympus DP50 CCD camera and analySIS software. For signal intensity comparison, individual experiments were performed in different wells on the same glass slide. Furthermore, exposure times, gain settings and so on were kept constant during image acquisition. Image handling was done in Adobe Photoshop.

\section{ACKNOWLEDGMENTS}

We are grateful to lab members M. Rosbash and D. Libri for comments on the manuscript. This work was supported by grants from the Danish National Scientific Research Council and the Novo Nordisk foundation (to T.H.J.).

Received June 17, 2005; accepted August 3, 2005.

\section{REFERENCES}

Chartrand, P., Bertrand, E., Singer, R.H., and Long, R. 2000. Sensitive and high-resolution detection of RNA in situ. Methods Enzymol. 318: 493-506.

Dower, K., Kuperwasser, N., Merrikh, H., and Rosbash, M. 2004. A synthetic A tail rescues yeast nuclear accumulation of a ribozymeterminated transcript. RNA 10: 1888-1899.

Jacobsen, N., Nielsen, P.S., Jeffares, D.C., Eriksen, J., Ohlsson, H., Arctander, P., and Kauppinen, S. 2004. Direct isolation of poly $(\mathrm{A})^{+}$RNA from $4 \mathrm{M}$ guanidine thiocyanate-lysed cell extracts using locked nucleic acid-oligo(T) capture. Nucleic Acids Res. 32: e64.

Jensen, T.H., Patricio, K., McCarthy, T., and Rosbash, M. 2001. A block to mRNA nuclear export in S. cerevisiae leads to hyperadenylation of transcripts that accumulate at the site of transcription. Mol. Cell 7: 887-898.

Kadaba, S., Kruege, A., Trice, T., Krecic, A.M., Hinnebusch, A.G., and Anderson, J. 2004. Nuclear surveillance and degradation of hypomodified initiator tRNA ${ }^{\mathrm{Met}}$ in S. cerevisiae. Genes \& Dev. 18: 12271240.

Koshkin, A.A., Singh, S.K., Nielsen, P., Rajwansh, V.K., Kumar, P., Meldgaard, M., Olsen, C.E., and Wengel, J. 1998. LNA (locked nucleic acids): Synthesis, of the adenine, cytosine, guanine, 5methylcytosine, thymine and uracil bicyclonucleside monomers, oligomerisation and unprecedented nucleic acid recognition. Tetrahedron 54: 3607-3630.

LaCava, J., Houseley, J., Saveanu, C., Petfalski, E., Thompson, E., Jacquier, A., and Tollervey, D. 2005. RNA degradation by the exosome is promoted by a nuclear polyadenylation complex. Cell 121: 713-724.

Schneiter, R., Kadowaki, T., and Tartakoff, A.M. 1995. mRNA transport in yeast: Time to reinvestigate the functions of the nucleolus. Mol. Biol. Cell 6: 357-370.

Stutz, F., Kantor, J., Zhang, D., McCarthy, T., Neville, M., and Rosbash, M. 1997. The yeast nucleoporin riplp contributes to multiple export pathways with no essential role for its FG-repeat region. Genes \& Dev. 11: 2857-2868.

Thomsen, R., Libri, D., Boulay, J., Rosbash, M., and Jensen, T.H. 2003. Localization of nuclear retained mRNAs in Saccharomyces cerevisiae. RNA 9: 1049-1057.

Valoczi, A., Hornyik, C., Varga, N., Burgyan, J., Kauppinen, S., and Havelda, Z. 2004. Sensitive and specific detection of microRNAs by Northern blot analysis using LNA-modified oligonucletide probes. Nucleic Acids Res. 32: e175.

Vanacova, S., Wolf, J., Martin, G., Blank, D., Dettwiler, S., Friedlein, A., Langen, H., Keith, G., and Keller, W. 2005. A new yeast poly(A) polymerase complex involved in RNA quality control. PLoS Biol. 3: e189.

Wienholds, E., Kloosterman, W.P., Miska, E., Alvarez-Saavedra, E., Berezikov, E., de Bruijn, E., Horvitz, H.R., Kauppinen, S., and Plasterk, R.H.A. 2005. MicroRNA expression in zebrafish embryonic development. Science 309: 310-311.

Wyers, F., Rougemaille, M., Badis, G., Rousselle, J.C., Dufour, M.E., Boulay, J., Regnault, B., Devaux, F., Namane, A., Seraphin, B., et al. 2005. Cryptic Pol II transcripts are degraded by a nuclear quality control pathway involving a new poly(A) polymerase. Cell 121: 725-737. 

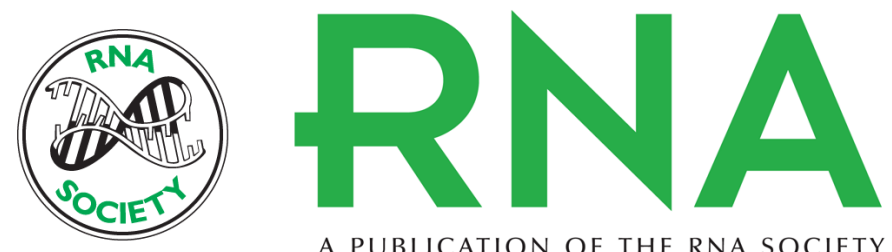

A PUBLICATION OF THE RNA SOCIETY

\section{Dramatically improved RNA in situ hybridization signals using LNA-modified probes}

RUNE THOMSEN, PETER STEIN NIELSEN and TORBEN HEICK JENSEN

RNA 2005 11: 1745-1748

References This article cites 14 articles, 6 of which can be accessed free at: http://rnajournal.cshlp.org/content/11/11/1745.full.html\#ref-list-1

\section{License}

Email Alerting Service right corner of the article or click here.

To subscribe to RNA go to:

http://rnajournal.cshlp.org/subscriptions 